\title{
EFFECTS OF THE COMPLEX OF MAGNESIUM AND CHROMIUM CITRATES ON THE CARBOHYDRATE METABOLISM IN THE BLOOD OF RATS WITH EXPERIMENTAL DIABETES MELLITUS
}

\author{
O. A. Shatynska, R. Ya. Iskra, O. Z. Svarchevska \\ sh_poshta@meta.ua
}

Institute of Animal Biology NAAS,

38 Vasyl Stus str., Lviv 79034, Ukraine

The article presents the results of investigation of the influence of the complex of magnesium $\left(\mathrm{Mg}^{2+}\right)$ and chromium $\left(\mathrm{Cr}^{3+}\right)$ citrates on the activity of carbohydrate metabolism key enzymes, and also on the concentration of insulin and C-peptide in the blood of rats with experimental diabetes. The complex of magnesium and chromium citrates in doses $250 \mathrm{mg} \mathrm{Mg} / \mathrm{kg}$ bw plus $25 \mathrm{mkg} \mathrm{Cr} / \mathrm{kg}$ bw and $250 \mathrm{mg} \mathrm{Mg} / \mathrm{kg} \mathrm{bw} \mathrm{plus} 10 \mathrm{mkg} \mathrm{Cr} / \mathrm{kg}$ bw was added to the drinking water for all animals during 30 days. Experimental diabetes in animals was induced by a single intraperitoneal administration of a solution of alloxane monohydrate ("Synbios") at a dose of $150 \mathrm{mg} / \mathrm{kg}$ body weight. The glucose-6-phosphate dehydrogenase (G-6-PDH) and lactate dehydrogenase (LDH) activities in erythrocyte lizates, glucose, insulin and C-peptide concentrations in blood plasma were investigated.

It was found that experimental diabetes indused the decreased of glucose-6-phosphate dehydrogenase activity, insulin and C-peptide concentrations, and the increased lactate dehydrogenase activity and glucose concentration. The complex of magnesium and chromium citrates, which was added with water to the animals' diet during four weeks, led to a positive normalizing effect. It was shown by a credible increase of insulin and $C$-peptide concentrations and followed by a decrease of glucose concentration in the blood plasma.

Thus received results demonstrate that the addition of the investigated complex compound may become a basis for a development a new methods, which will help to correct the emergence and development of complications for diabetes mellitus in future.

Keywords: DIABETES MELLITUS, CARBOHYDRATE METABOLISM, INSULIN, MAGNESIUM CITRATE, CHROMIUM CITRATE

\section{КОМПЛЕКСНИЙ ВПЛИВ ЦИТРАТІВ МАГНІЮ ТА ХРОМУ НА ВУГЛЕВОДНИЙ ОБМІН У КРОВІ ЩУРІВ 3 ЕКСПЕРИМЕНТАЛЬНИМ ДІАБЕТОМ}

\author{
О. А. Шатинська, Р. Я. Іскра, О. 3. Сварчевська \\ sh_poshta@meta.ua
}

Інститут біології тварин НААН,

вул. В. Стуса, 38, м. Львів, 79034, Україна

У статті наведені дані досліджень впливу комплексу цитратів магнію $\left(\mathrm{Mg}^{2+}\right)$ і хрому $\left(\mathrm{Cr}^{3+}\right)$ на активність ключових ензимів вуглеводного обміну, а також конщентрацію інсуліну і С-пептиду в крові шурів з експериментальним иукровим діабетом. Комплекс иитратів магнію і хрому у дозах $250 \mathrm{мz} \mathrm{Mg/ \kappa г}$ маси тіла і 25 мкг Сr/кг маси тіла, а також 250 мг Mg/кг маси тіла і 10 мкг Сr/кг маси тіла протягом 30 днів додавали до питної води. Експериментальний иукровий діабет у тварин індукували одноразовим внутрішньоочеревинним введенням розчину алоксан моногідрату ("Синбіас») з розрахунку 150 мг/кг маси тіла. Досліджували активність глюкозо-6-фосфатдегідрогенази (Г-6-ФДГ) і лактатдегідрогенази (ЛДГ) у лізатах еритрочитів, концентрачію глюкози, інсуліну і С-пептиду у плазмі крові дослідних тварин.

Виявлено, що за умов експериментального иукрового діабету спостерігалось зниження активності глюкозо-6-фосфатдегідрогенази, концентрації інсуліну і C-пептиду та підвищення активності лактатдегідрогенази і конщентрації глюкози. Комплекс иитратів магнію та хрому, який протягом чотирьох тижнів разом з питною водою додавали до рачџіону тварин, виявляв позитивний нормалізаційний ефект. Це проявлялось вірогідним підвищенням концентращії інсуліну і C-пептиду із наступним зниженням концентрації глюкози у плазмі крові.

Таким чином, наші дані демонструють, що добавка досліджуваної комплексної сполуки у перспективі може бути використана для розробки засобів корекиії виникнення і розвитку ускладнень за иукрового діабету. 


\title{
КОМПЛЕКСНОЕ ВОЗДЕЙСТВИЕ ЦИТРАТОВ МАГНИЯ И ХРОМА НА УГЛЕВОДНЫЙ ОБМЕН В КРОВИ КРЫС С ЭКСПЕРИМЕНТАЛЬНЫМ ДИАБЕТОМ
}

\author{
Е. А. Шатинская, Р. Я. Искра, О. 3. Сварчевская \\ sh_poshta@meta.ua
}

Институт биологии животных НААН,

ул. В. Стуса, 38, г. Львов, 79034, Украина

В статье приведены данные исследований влияния комплекса ичитратов магния $\left(\mathrm{Mg}^{2+}\right)$ и хрома $\left(\mathrm{Cr}^{3+}\right)$ на активность ключевых ферментов углеводного обмена, а также концентрацию инсулина и С-пептида в крови крыс с экспериментальным сахарным диабетом. Комплекс иитратов магния и хрома в дозах 250 мг Mg/кг и 25 мкг Cr/кг массы тела, а также 250 мг $\mathrm{Mg} / \kappa 2$ и 10 мкг Cr/кг массы тела в течении 30 дней добавляли к питьевой воде. Экспериментальный сахарный диабет у животных индуиировали путем однократного внутрибрюшинного введения раствора алоксан моногидрата ("Синбиас») из расчета 150 мг/кг массы тела. Исследовали активность глюкозо-6-фосфатдегидрогеназы (Г-6-ФДГ) и лактатдегидрогеназы (ЛДГ) в лизатах эритрочитов, кониентраџию глюкозы, инсулина и C-пептида в плазме крови опытных животных.

Выявлено, что в условиях экспериментального сахарного диабета наблюдалось снижение активности глюкозо-6-фосфатдегидрогеназы, конщентрации инсулина и С-пептида, повышение активности лактатдегидрогеназы и концентрации глюкозы. Комплекс иитратов магния и хрома, который в течение четьгрех недель вместе с питьевой водой добавляли в рацион животных, проявлял положительный нормализируюший эффект. Это проявлялось достоверным повымением кониентрации инсулина и С-пептида с последующим снижением концентрации глюкозы в плазме крови.

Таким образом, наши данные показывают, что добавка исследуемого комплексного соединения в перспективе может быть использована для разработки средств коррекции возникновения и развития усложнений при сахарном диабете.

\section{Ключевые слова: САХАРНЫЙ ДИАБЕТ, УГЛЕВОДНЫЙ ОБМЕН, ИНСУЛИН, ЦИТРАТ МАГНИЯ, ЦИТРАТ ХРОМА}

Diabetes mellitus is a metabolic disorder characterized by hyperglycemia and insufficiency of secretion or action of endogenous insulin [9]. While, diabetes is characterized by disorders in all kinds of metabolism, in the first place is carbohydrate metabolism, just the chronic hyperglycemia play a principal role in the mechanism of development of complications of this disease $[4 ; 5 ; 16]$.

Magnesium plays a significant role in glucose and insulin metabolism, mainly through its impact on tyrosine kinase activity, by transferring the phosphate from ATP to protein. Magnesium may also affect phosphorylase $b$ kinase activity by releasing glucose-1-phosphate from glycogen. In addition, magnesium may directly affect glucose transporter 4 (GLUT4) activity and help to regulate glucose translocation into the cell [19].

Magnesium deficit have a negative effect on the activity and insulin secretion, which promotes to insulin resistance and diabetes progressing [15].

Biochemical action of the insulin also is related to chromium (III), because it stimulates creating of the triple complex by forming disulfide bonds between disulfide sites of insulin and sulfide group of the mitochondrial membrane [14].

It is known that citrates of trace elements are used in technological processes of food production. At the same time, these salts are valuable compounds of macro- and micronutrients which are necessary to ensure the normal course of physiological and biochemical processes in the body and prevention a number of metabolic disorders (such as diabetes mellitus). So, magnesium and chromium citrats compounds are safe, exhibit antioxidant action, are well absorbed by the body and are nontoxic compounds. In addition, the bioavailability of magnesium and chromium in nanocitrate com- 
pounds is higher than the bioavailability of their inorganic forms $[6 ; 8]$.

Our previous investigations have shown a positive but separate effects of magnesium citrate and chromium citrate as the compounds for prevent the diabetes. So the purpose of this research was to investigate the complex effects of different doses of magnesium citrate and chromium citrate on the state of carbohydrate metabolism in the blood of rats with experimental diabetes. The research could give us an opportunity to search for new ways of correction pathological changes, which are the cause of emergence and complications in the disease.

\section{Materials and methods}

The experimental tests were conducted on the 25 white female Wistar rats (130-150 g), kept in conditions of the vivarium of the Institute of Animal Biology NAAS. Animals were housed in individual cages for the appropriate conditions of lighting and temperature, and were allowed to eat and drink according to the standard diet. All experimental animals were divided into 5 groups: control group (CG), with 5 non-diabetic control rats, the diabetic group (DG), with 5 diabetic rats without any treatment for the disease and two research groups $(\mathrm{RG})$, with 5 diabetic rats each treated by complexes of magnesium and chromium salts. The complex of magnesium citrate $\left(\mathrm{C}_{6} \mathrm{H}_{6} \mathrm{O}_{7} \mathrm{Mg}\right)$ and chromium citrate $\left(\mathrm{C}_{6} \mathrm{H}_{5} \mathrm{O}_{7} \mathrm{Cr}\right)$ in doses: $\mathrm{RG} 1-250 \mathrm{mg}$ $\mathrm{Mg} / \mathrm{kg}$ bw and $25 \mathrm{mkg} \mathrm{Cr} / \mathrm{kg}$ bw; RG2 - $250 \mathrm{mg}$ $\mathrm{Mg} / \mathrm{kg}$ bw and $10 \mathrm{mkg} \mathrm{Cr} / \mathrm{kg}$ bw was added to the drinking water for all animals. Such activities were carried out 30 days for the profilaction of the diabetes. The experimental diabetes was induced on the backdrop of a 24-hour fasting by a single intraperitoneal administration of alloxan monohydrate ("Synbias") in dosage $150 \mathrm{mg} / \mathrm{kg}$ body weight in $5 \%$ saline solution. High blood sugar has been detected by measuring blood glucose, collected from the tail vein, using a portable blood glucose meters ("Gamma-M"). On the day 30, animals were withdrawn from the experiment with the help of easy airborn anesthesia by decapitation. The plasma and red blood cells of rats selected after the experiment were the main materials for examination. The concentration of blood glucose [10], insulin and
C-peptide in plasma and activity of the main enzymes of the carbohydrate metabolism [18], that are glucose-6-phosphate dehydrogenase (G6PDH) and lactate dehydrogenase (LDH) in blood were determined.

The concentration of blood glucose was determined by analytic set "Chromeglucosa+" (Ukraine). The concentrations of insulin and C-peptide in plasma were determined by IFA method with used standard ELISA sets.

The activity of carbohydrate metabolism was estimated with a spectrophotometric method based on a use of conjugate oxidizing systems or reduced nicotinamide coenzymes. Spectrophotometric measurements were implemented on a spectrophotometer $S F 26$ at $\mathrm{t}+37^{\circ} \mathrm{C}$. The intake at $340 \mathrm{~nm}$ was estimated at time interval $3 \mathrm{~min}$. A minimolar coefficient of extinction $\mathrm{NADH}+\mathrm{H}^{+}$and $\mathrm{NADHPH}+\mathrm{H}^{+}(6.22$ at $340 \mathrm{~nm})$ was used. Lactate dehydrogenase (EC 1.1.1.27) enzyme catalyzes the conversion of lactate to pyruvic acid and back, as it converts NAD ${ }^{+}$to NADH and back. Direct reaction occurs only under high level of lactate, while under oxygen deficiency the reverse reaction take place. Glucose-6-phosphate dehydrogenase (EC 1.1.1.49) - enzyme participates in the pentose phosphate pathway that supplies the maintaining the level of the NADPH. This reaction is almost irreversible and enzyme activity was determined by the recovery rate of $\mathrm{NADP}^{+}$.

Statistical analysis was performed on statistically significant differences between experimental groups by Student's $t$-criterion using the Microsoft Excel program package VBA. The value of the results was ascertained at $\mathrm{P} \leq 0.05$.

\section{Results and discussion}

Conducted investigation of the activity of main enzymes of carbohydrate metabolism in red blood cells of rats of the first experimental group showed the tendency to the decrease of the G6PDH activity on $14 \%$ and the increase of the LDH activity on $1.6 \%$ comparing to the results in CG (table 1 ). In turn, it was demonstrated that the complex of magnesium and chromium citrates shows stabilizing influence on biochemical processes of glucose transformation. As a result, comparing outcomes of RG2 and RG3 to the outcomes of RG1, the increase 
of the G6PDH activity (11.9\% and $5.3 \%$ ) and the decrease of the LDH activity $(2.8 \%$ and $8.6 \%)$ was observed. However, these changes of enzyme activity were not significant. Magnesium is directly involved in numerous important biochemical reactions, and particularly is a necessary cofactor in over 300 enzymatic reactions and specifically in all processes involved in the utilization and transfer of adenosine triphosphate (ATP). Thus, intracellular $\mathrm{Mg}$ is a critical cofactor for several enzymes in carbohydrate metabolism and the activated Mg-ATP complex is required for all of the rate-limiting enzymes of glycolysis, also it regulates the activity of all enzymes involved in phosphorylation reactions [1]. In turn, chromium, which was included to the complex compound, is involved in the regulation of the carbohydrate metabolism by intensification insulin effect of concerning glucose conversion [17].

According to the data displayed in the table 2, the concentration of insulin in DG is significant decreasing $(34.5 \%)$ than in CG of rats. This may be due to increased hyperglycemia, which is a cause of the destruction of the pancreatic $\beta$-cell, and this is directly connected to the decreasing of insulin sensitivity and disturbers in secretion of this hormone [13].

Nevertheless, for the complex effect citrates of magnesium and chromium (in doses $250 \mathrm{mg} \mathrm{Mg}^{2+} / \mathrm{kg}$ bw and $25 \mathrm{mkg} \mathrm{Cr}^{3+} / \mathrm{kg}$ bw) in the animals of RG1 had shown significant increase of the insulin concentration on $49.4 \%$ compare to the index of the animals of the DG.
Magnesium affects insulin secretion by changing the sensitivity of the Langerhans islet $\beta$ cells to glucose [3]. In turn, chromium is biologically active in the oligopeptide chromodulin, which activates the action of insulin by binding of hormone to receptors on the cells surface $[2,7]$.

It is known, that C-peptide is the protein part of proinsulin molecule, which is created in the insulin synthesis process. At physiological increasing of glucose concentration proinsulin decomposes to the insulin and C-peptide, which secretion to the blood. Quantity of circulating C-peptide in blood is equivalent of quantity of insulin [12]. Displayed data in the table 2 illustrates that the concentration of C-peptide in the blood plasma of the animals of DG reliably decreased (64.4\%) in comparison to the indexes of the animals of the control group. Decreased concentration of C-peptide in blood plasma of animals with experimental diabetes mellitus, which have been had background decreasing concentration of insulin, indicates normalization of secretion of the hormone by $\beta$-cells of the pancreas. But in blood plasma of animals of RG1 and RG2, which received magnesium and chromium citrates with water, the concentration of C-peptide reliably increased. It indicates about normalization of the secretory function of the pancreas.

At lowering the insulin concentration, a significant increase of glucose concentration is observed in the blood plasma of animals with experimental diabetes, which is not observed in the blood plasma of rats from the control group (fig.).

Activities of the glucose-6-phosphate dehydrogenase and lactate dehydrogenase in rats' red blood cells, $\mu \mathrm{mol} / \mathrm{min} \times \mathbf{m g}$ of protein $(\mathrm{M} \pm \mathrm{m}, \mathrm{n}=5)$

\begin{tabular}{|l|c|c|c|c|}
\hline \multirow{2}{*}{ Parameters } & \multicolumn{4}{c|}{ Groups } \\
\cline { 2 - 5 } & CG & DG & RG1 & RG2 \\
\hline Glucose-6-phosphate dehydrogenase & $11.07 \pm 0.90$ & $9.52 \pm 0.45$ & $10.65 \pm 0.51$ & $10.02 \pm 0.22$ \\
\hline Lactate dehydrogenase & $103.09 \pm 5.88$ & $104.70 \pm 3,61$ & $101.74 \pm 10.60$ & $95.74 \pm 3.07$ \\
\hline
\end{tabular}

The content of the insulin and $\mathrm{C}$-peptide in rat's blood plasma $(\mathrm{M} \pm \mathrm{m}, \mathrm{n}=5)$

\begin{tabular}{|l|c|c|c|c|}
\hline \multirow{2}{*}{\multicolumn{1}{c|}{ Parameters }} & \multicolumn{4}{c|}{ Groups } \\
\cline { 2 - 5 } & CG & DG & RG1 & RG2 \\
\hline C-peptide, $\mathrm{ng} / \mathrm{ml}$ & $3.81 \pm 0.02$ & $1.35 \pm 0.007 * * *$ & $3.00 \pm 0.09^{\# \# \#}$ & $4.56 \pm 0.01^{\# \#}$ \\
\hline Insulin, $\mu \mathrm{U} / \mathrm{ml}$ & $3.74 \pm 0.01$ & $2.45 \pm 0.01^{* * *}$ & $3.66 \pm 0.01^{\# \# \#}$ & $3.24 \pm 0.02^{\# \# \#}$ \\
\hline
\end{tabular}

Note: here and thereafter $* * *-\mathrm{P}<0.001$ significant differences between indexes of DG and $\mathrm{CG}$; \#\# $-\mathrm{P}<0.01$; \#\#\# - $\mathrm{P}<0.001$ significant differences between indexes of RG1, RG2 and DG. 


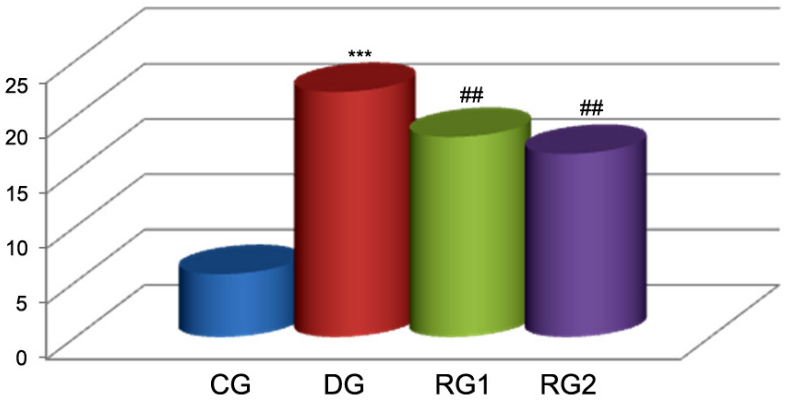

Fig. Glucose concentration in the rats' blood plasma, $\mathrm{mmol} / \mathrm{L}$

Increased glucose levels in the blood may be the result of deviation of intracellular glucose metabolism, reducing its utilization or lowering of synthesis and increase of the glycogen catabolism in the liver [5].

According to the information given in the diagram, glucose concentration in the blood of animals from RG1, RG2 was reliably decreased $(18.4 \%$ and $25.3 \%)$ as they received the complex of magnesium and chronium citrates with water. The results in DG are completely different.

Normalization of the carbohydrate metabolism may be predetermined by the influence of the complex of $\mathrm{Mg}^{2+}$ and $\mathrm{Cr}^{3+}$ citrates on the maintaining of normal glucose metabolism. It can be reached via use of insulin hormone. Chromium acts by enhancing or potentiating insulin action through increasing the number of receptors, their activation and binding of a hormone to them [11]. Magnesium is an essential ion involved in glucose homeostasis at multiple levels as it plays an important role in the activities of various enzymes involved in glucose oxidation and may play a role in the release of insulin [3].

\section{Conclusion}

1. Experimental diabetes is accompanied by disorders of carbohydrate metabolism. It appears as the increasing of glucose concentrate and decreasing of insulin concentrate in blood.

2. Appliance of the complex magnesium and chromium citrates leads to normalization of carbohydrate metabolism. It could be caused by positive influence of the studied compounds on the secretion and activity of the insulin. Complete response to the insulin action affects the capture of glucose by cells and its utilization.
Perspectives for further research. Use of magnesium and chromium citrates in perspective may be the basis for developing new ways to correct pathological changes of carbohydrate metabolism, which predetermine the emergence and development of complications under diabetes mellitus.

1. Barbagallo M., Dominguez L. J., Brucato V., Antonio Galioto A., Pineo A., Ferlisi A., Tranchina E., Belvedere M., Putignano E., Costanza G. Magnesium metabolism in insulin resistance, metabolic syndrome, and type 2 diabetes mellitus. New perspectives in magnesium research, Springer London, 2007, pp. 213-223.

2. Cefalu W. T., Hu F. B. Role of chromium in human health and in diabetes. Diabetes Care, 2004, vol. 27, no. 11, pp. 2741-2751.

3. Chetan P. Hans, Dharam P. Chaudhary, Devi D. Bansal. Effect of magnesium supplementation on oxidative stress in alloxanic diabetic rats. Magnesium Research, 2003, vol. 16, no. 1, pp. 13-19.

4. Fediv O. I., Marchuk Yu. F., Voloshyna L .A. Peculiarities of an affection of the hepatobiliary systems in patients with diabetes mellitus. Bukovinian Medical Herald, 2008, vol. 12, no. 4, pp. 126-131. (in Ukrainian)

5. Galenova T., Raksha N., Savchuk O., Ostapchenko L. Functioning of some key enzymes of carbohydrate metabolism in rats under experimental type 2 diabetes. Experimental and Clinical Physiology and Biochemistry, 2011, vol. 2, no. 54, pp. 13-21. (in Ukrainian)

6. Gulich M. P., Kharchenko O. O., Yemchenko N. L., Yermolenko V.P., Moiseienko I. Ye. Magnesium citrate, obtained on the basis of aquananotechnology: chemical and biological characteristics. Environment and health, 2014, vol. 71, no. 4, pp. 14-18.

7. Iskra R. Ya, Vlizlo V. V. Peculiarities of antioxidant defense system in erythroid cells and tissues of pigs under action of chromium chloride. The Ukrainian Biochemical Journal, 2012, vol. 85, no. 3, pp. 96-102. (in Ukrainian)

8. Iskra R. Ya. Some indices of antioxidant protection and carbohydrates metabolism in rats' tissues at chromium nanocytrate action. Studia Biologica, 2011, vol. 5 , no. 3 , pp. $49-58$.

9. Maritim A. C., Sanders A., Watkins 3. J. Diabetes, oxidative stress, and antioxidants: a review. Journal of biochemical and molecular toxicology, 2003, vol. 17, no. 1 , pp. 24-38.

10. Menshikov V. V. Laboratory Research Methods in Clinic. Medicine, 1987, pp. 174-177. (in Russian)

11. O'Connell B. S. Select vitamins and minerals in the management of diabetes. Diabetes Spectrum, 2001, vol. 14, no. 3, pp. 133-148.

12. Pankiv V. I. Diabetes Mellitus: Diagnostic Criteria, Etiology and Pathogenesis. International journal of endocrinology, 2013, vol. 8, no. 56, pp. 53-68. (in Ukrainian) 
13. Prystupok O. Metabolic therapy for patients with diabetes mellitus. International journal of endocrinology, 2010, vol. 6, pp. 6-11. (in Ukrainian)

14. Smolyar V. I., Petrashenko H. I. Alimentary hypo- and hypermicroelementosis. Problems of nutrition, 2005, vol. 4, pp. 40-42. (in Ukrainian)

15. Suslyk A. I. Peculiarities of trace element content in the blood of patients with type 2 diabetes mellitus and obesity. Experimental and Clinical Physiology and Biochemistry, 2012, vol. 59, no. 3, pp. 54-59. (in Ukrainian)
16. Ta S. Diagnosis and classification of diabetes mellitus. Diabetes care, 2014, vol. 37, pp. 81-90.

17. Vincent J. B. The biochemistry of chromium. The Journal of nutrition, 2000, vol. 130, no. 4, pp. 715-718.

18. Vlizlo V. V., Fedoruk R. S., Ratych I. B. Laboratory methods of research in biology, stockbreeding and veterinary medicine. A handbook. Ed. by. V. V. Vlizlo. Lviv, Spolom, 2012, 764 p. (in Ukrainian)

19. Volpe S. L. Magnesium in disease prevention and overall health. Advances in Nutrition: An International Review Journal, 2013, vol. 4, no. 3, pp. 378-383. 